University of Nebraska - Lincoln

DigitalCommons@University of Nebraska - Lincoln

Faculty Publications, College of Dentistry

Dentistry, College of

6-1969

\title{
Magnitude and Pattern of Compensatory Growth in Rats after Cold Exposure
}

\author{
Marjorie Lee \\ University of Nebraska - Lincoln \\ P. C. Chu \\ University of Hong Kong \\ H. C. Chan \\ University of Hong Kong
}

Follow this and additional works at: https://digitalcommons.unl.edu/dentistryfacpub

Part of the Other Medicine and Health Sciences Commons

Lee, Marjorie; Chu, P. C.; and Chan, H. C., "Magnitude and Pattern of Compensatory Growth in Rats after Cold Exposure" (1969). Faculty Publications, College of Dentistry. 6.

https://digitalcommons.unl.edu/dentistryfacpub/6

This Article is brought to you for free and open access by the Dentistry, College of at DigitalCommons@University of Nebraska - Lincoln. It has been accepted for inclusion in Faculty Publications, College of Dentistry by an authorized administrator of DigitalCommons@University of Nebraska - Lincoln. 


\title{
Magnitude and pattern of compensatory growth in rats after cold exposure
}

\author{
By MARJORIE M. C. LEE, ${ }^{1}$ P. C. CHU ${ }^{2}$ \& H. C. CHAN ${ }^{2}$ \\ Department of Anatomy, University of Hong Kong
}

It is a common observation that normal growth is affected or suppressed in young individuals by environmental adversities and physical disturbances. On the other hand, when health or favorable conditions are restored, the tempo of growth promptly accelerates as if the individual is trying to make up for the growth debt incurred. Tanner has referred to this increased growth rate after diseases or starvation as compensatory or 'catch-up' growth, a topic on which he has written eloquently and fully in a number of articles $(1963 a, b)$. He considers this compensatory growth as a 'self-stabilizing' or 'target-seeking' phenomenon in the regulatory control of growth.

Growth of young rats is slowed by severe cold and increased by warmth (Héroux \& Gridgeman, 1958; Chevillard, Portet \& Cadot, 1963). The aim of the present investigation is to show the magnitude and pattern of compensatory growth in rats after single and repeated cold exposures; to evaluate age differentials in this response; and to study the pattern and relative rate of compensatory growth in the various bony segments of the appendages.

\section{MATERIALS AND METHODS}

Male albino laboratory rats, recently weaned, were used in the present experiments. The rats were kept singly in separate cages, and given water and Purina rat chow in excess. Two rooms were used: a warm one of $28 \pm 1{ }^{\circ} \mathrm{C}$ and a cold one of $5 \pm 1{ }^{\circ} \mathrm{C}$. The rooms were artificially lit for $12 \mathrm{~h}$ each day.

The experiments were carried out in two series. For each series the rats were divided into three groups in the following manner. Every three rats of the same body weight were assigned one to each group, so that the three groups of rats were identical in mean size and degree of variation, and presumably comparable in growth potential at the beginning of the experiments. Both experimental series took 16 weeks to complete.

1 Author's address: College of Dentistry, University of Nebraska, Lincoln, Nebraska 68503, U.S.A.

2 Author's' address: Department of Anatomy, University of Hong Kong, Li Shu Fan Building, Hong Kong. 
Experiment I. Rats 26 days of age were divided as follows: 11 were kept at $28{ }^{\circ} \mathrm{C}$ (W 1 rats); 10 at $5{ }^{\circ} \mathrm{C}$ (C rats); and 11 were alternated weekly between the two temperatures (AT rats).

Experiment II. Rats 23 days of age were divided as follows: 12 were kept at $28^{\circ} \mathrm{C}$ (W2 rats); another 12 rats were kept at $5{ }^{\circ} \mathrm{C}$ during the first two experimental weeks (23-27 days of age), and then transferred to $28^{\circ} \mathrm{C}$ for the rest of the period (A rats); 13 rats were kept first in the warm room, then transferred to $5{ }^{\circ} \mathrm{C}$ during the 5 th and 6 th experimental weeks (52-65 days of age), and then returned to $28^{\circ} \mathrm{C}$ for the rest of the experiment (B rats).

Total length was measured from tip of the nose to end of the tail with the rat in vertical position; tail length was measured from the anal opening to the tail end (Chan, Chu \& Lee, in preparation). Body length of the rats was obtained by deducting the tail length from the total length. Gross measurements were carried out weekly, except for the AT rats, which were measured daily during the first 8 weeks; after that a weekly measurement was taken. The measurements were obtained to the nearest millimeter.

The rats were X-rayed once every fortnight with non-screened films. Light ether anesthesia was given during the radiography; the limbs and tails were held with cellulose adhesive tape. Length of six bones, with their epiphyses, if present, was measured along the longitudinal axis. These six bones consisted of three caudal vertebrae (Cd 6, 13, and 23) representing the proximal, mid and distal parts of tail; and three hind-limb bones (tibia, metatarsal 3, and mid-phalanx 3). Skeletal measurements on the radiographs were performed under a magnifying lens with a helios caliper, and read to $\frac{1}{20} \mathrm{~mm}$.

Student's $t$ test was used to determine the significance between the group means in many of the measurements. $P<0.01$ was chosen as the level of significance for all the tests in the present series.

\section{FINDINGS}

\section{Gross measurements}

For Exp. I, findings on tail and body lengths are shown in Fig. 1. Growth reduction produced by the cold environment was more marked in all cases in the tail than in the body. The distance curves of the AT rats are characteristically step-like owing to different growth rates in the alternating weeks of cold and warm exposures. During the early part of the experiment, when the AT rats were measured daily, the change in growth rate appeared immediately with change of temperature. Since the growth rate did not differ obviously from day to day within a given week, weekly means and increment per week are shown. The tail length of the AT rats was significantly shorter than that of the W 1 controls. The body length of the AT rats, however, was significantly shorter than that of the controls only at the end of each cold exposure week; while the catch-up growth during the warm period caused so much increase that, by the end of each warm 


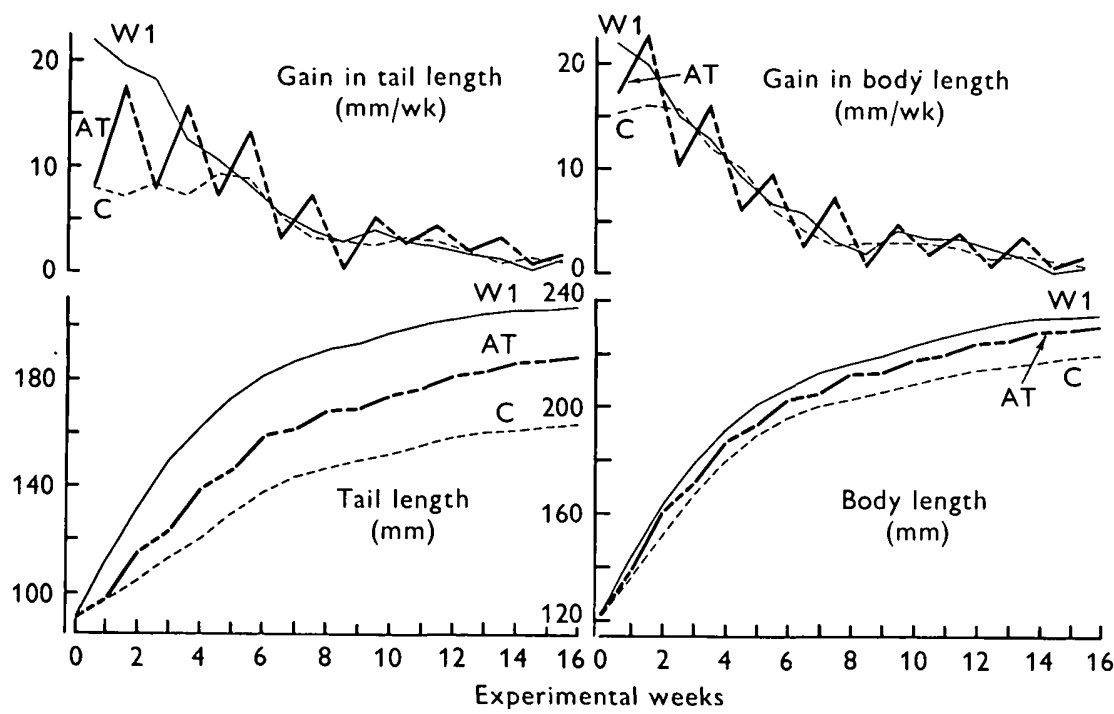

Fig. 1. Distance (lower) and incremental (upper) growth curves of tail and body length of the three rat groups in Exp. I. W I rats at $28^{\circ} \mathrm{C}$; C, rats at $5{ }^{\circ} \mathrm{C}$; AT, rats at $5^{\circ} \mathrm{C}$ and $28^{\circ} \mathrm{C}$ every alternate week.,$- 28^{\circ} \mathrm{C} ;---, 5^{\circ} \mathrm{C}$.

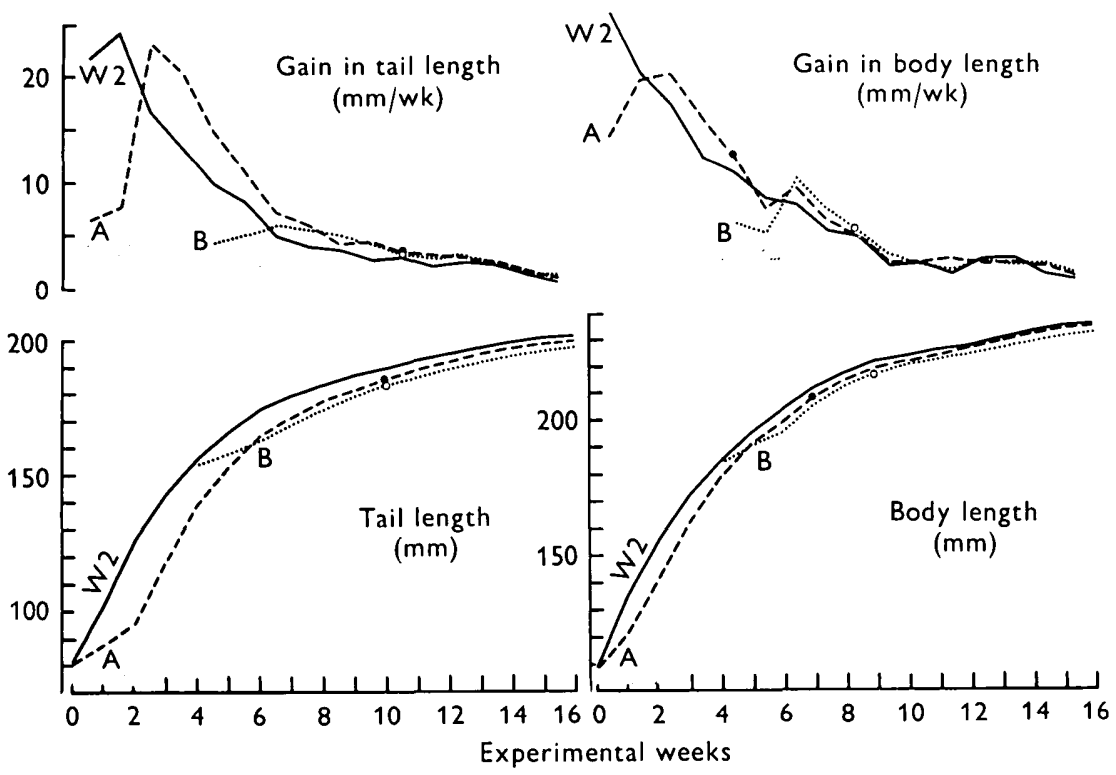

Fig. 2. Distance (lower) and incremental (upper) growth curves of tail and body length of the three rat groups in Exp. II. W2, Rats at $28^{\circ} \mathrm{C}$; A, rats at $5^{\circ} \mathrm{C}$ in 1 st and 2nd experimental weeks; $\mathrm{B}$, rats at $5^{\circ} \mathrm{C}$ in 5 th and 6 th experimental weeks. Shaded areas show periods of cold exposure. Circles on lines indicate time when lengths of A or B became insignificantly different from those of $\mathrm{W} 2$. 
week, there was no significant difference from the controls. Cold exposure later (15th experimental week) produced no significant shortening of the body.

The decreased growth rate of the $\mathrm{C}$ rats was manifest only during the first few weeks of cold exposure (Fig. 1). The gain in tail length varied from $36 \%$ to $58 \%$ of their contemporary W1 rats in the first four experimental weeks; the gain in body length was $70-80 \%$ during the first two experimental weeks. Later, adaptation to cold seemed to have been established, for their weekly gain became very similar to that of the W 1 rats. For the AT rats, great fluctuations in the rate of tail and body growth were observed after temperature changes throughout the whole period.

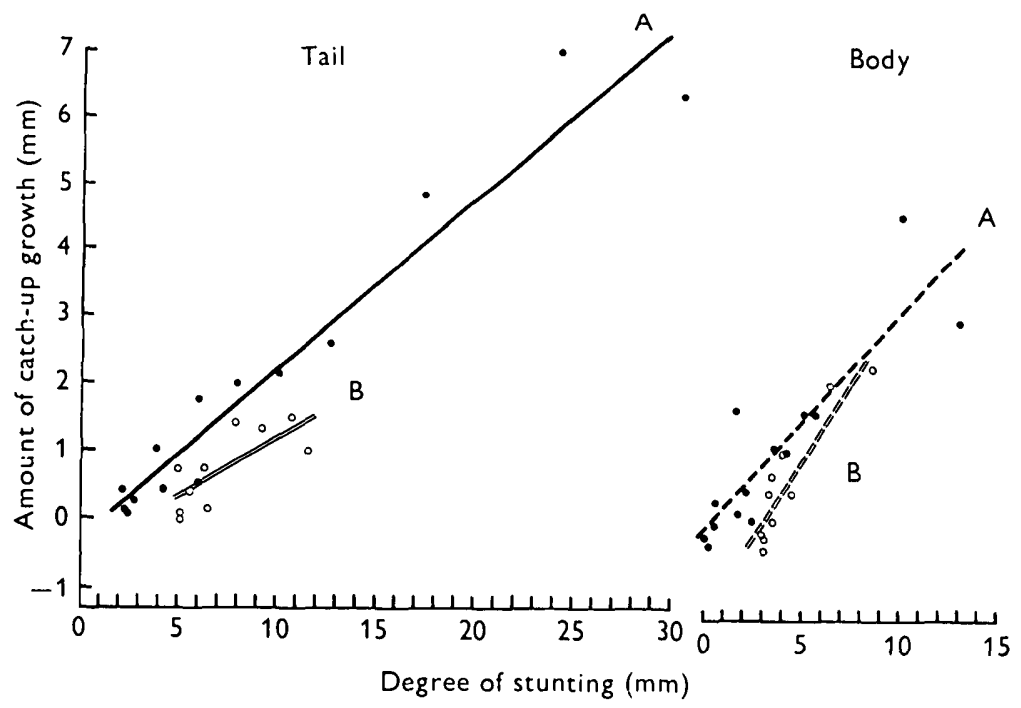

Fig. 3. Regression lines of the amount of compensatory growth (gain of A or B rats minus gain of W2) on the degree of stunting (length of W 2 rats minus length of $A$ or B) for tail and body lengths. A rats; $\mathrm{O}==\mathrm{O}, \mathrm{B}$ rats.

Findings from Exp. II are shown in Fig. 2. Growth retardation during the single cold exposure period, and prompt compensatory growth after return to the warm environment, occurred in both the tail and the body, and in the younger $A$ as well as the older B rats. During the 2-week periods of cold exposure, tail gain of the A rats was only about $30 \%$ of that of the warm controls (W2), while that of the $\mathrm{B}$ rats averaged about $50 \%$. Likewise, the rapid compensatory growth in tail length during the 2 weeks immediately after the end of cold exposure was more prominent in the $\mathrm{A}$ than in the $\mathrm{B}$ rats: the tail gain in the $\mathrm{A}$ rats averaged around $145 \%$ of that of the controls in contrast to $130 \%$ in the $\mathrm{B}$ rats. Not only was the compensation greater in the A rats, but the compensatory period (period of significantly faster growth) was longer also, extending over 8 weeks (from 3 rd to 10 th), in contrast to 4 weeks (from 6th to 10th) in the $B$ rats. By the end of the 10 th week the tail length of $A$ and $B$ rats was not significantly shorter than that of the $\mathrm{W} 2$ group. 
Differential response to environmental temperatures between A and B rats was less clear in body length. During the 2-week cold exposure period, the gain in body length of $\mathrm{A}$ rats averaged $75 \%$ of that of the control rats, while that of the $\mathrm{B}$ rats was about $60 \%$. During the first 2 weeks after returning to the warm environment, the growth acceleration in A and B groups was similar, at about $130 \%$ of the normal growth rate of the contemporary control group. For both groups (A and B), the period of significantly increased rate of growth in body length after termination of cold exposure lasted only for 2 weeks: A rats during the 3rd and 4th weeks and B rats during the 7th and 8th weeks. By the 7th week in the case of A rats and the 9th week in the B rats, the body length had caught up with that of the $\mathrm{W} 2$ rats.

The amount of compensatory growth and the degree of stunting showed a positive linear relationship, as is illustrated by the regression lines in Fig. 3 for both tail and body length measurements, in both the A and B groups of rats. The obtained linear correlation coefficients between the two variables are all high $(r=0.97$ and 0.76 for tail length and 0.88 and 0.92 for body length of the A and B rats respectively). Analysis of covariance (Snedecor, 1956) was carried out to compare the pairs of regression lines between the A and B rats in Fig. 3 for the tail and body lengths separately. For both length measurements the $\mathrm{A}$ and $\mathrm{B}$ rats do not differ significantly in slope (regression coefficient $b$ ), but differ significantly in elevation $(a)$. In both cases the lines of $\mathrm{B}$ rats are situated below those of the A rats. These results imply that for the same degree of stunting the older $\mathrm{B}$ rats tend to have a smaller amount of compensatory growth than the younger $\mathrm{A}$ rats.

\section{Radiographic measurements}

Radiographic measurements on the length of the three caudal vertebrae (Cd 6, 13, and 23), and the three hind-limb bones (tibia, metatarsal 3, and midphalanx 3) were made for the rats in both experimental series. The patterns of cold-retardation and warm-compensatory growth of the different segments of the appendicular bones in the various groups are shown in Figs. 4 and 5. In both figures the bone lengths were plotted as percentages of the corresponding controls.

Figure 4 shows the results of Exp. I. The bi-weekly radiographs were always taken at the end of a cold-warm cycle in the AT rats. For both the $\mathrm{C}$ and the AT rats, a clear stunting gradient was observed, since cold exposure affected the more distal bones more severely than the more proximal ones. The degree of stunting in all six bones was greater in the $\mathrm{C}$ than in the AT rats, and the stunting in both groups was greater in the caudal vertebrae than in the limb bones. For the $\mathrm{C}$ rats, all six bones measured were significantly shorter than those of the controls throughout the whole experimental period. For the AT rats, this held only for the three caudal vertebrae and the most distal limb bone (mid-phalanx 3 ), while the tibiae were never significantly shorter than the controls, and the metatarsal 3 were significantly shorter only during the first 6 weeks. 
Figure 5 illustrates the results of Exp. II. As in Exp. I, the caudal vertebrae were more severely stunted by cold than the hind-limb bones and generally they took a longer time to catch up with the control bones. More marked stunting was observed in the six bones of the A rats than in those of the B rats. The disto-proximal gradient of cold stunting was again observed, for stunting was markedly more evident in the most distal tail and limb bones of both the A and $B$ rats by the end of the fortnight of cold exposure. This gradient disappeared

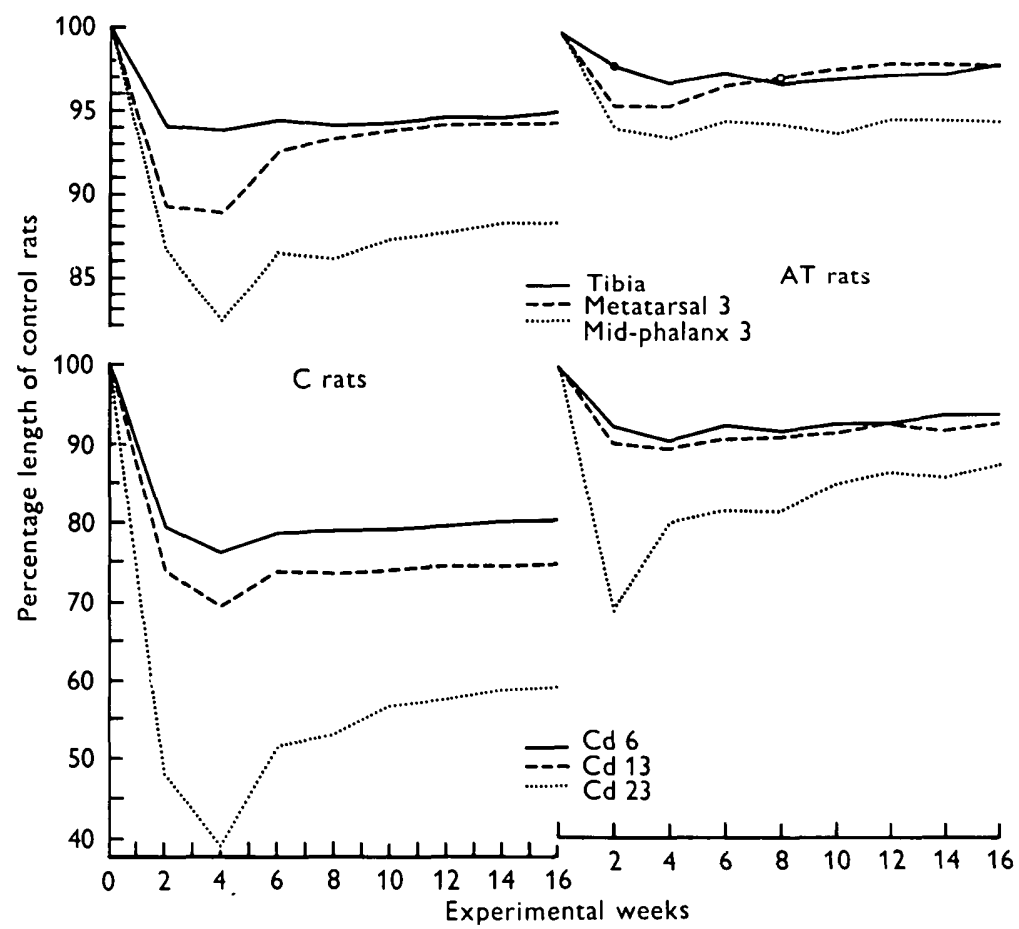

Fig. 4. Bone lengths of $\mathrm{C}$ and AT rats shown as percentages of $\mathrm{W} 1 \mathrm{rats}$. Circles on curves indicate time when bone lengths of AT rats became insignificantly shorter than those of $\mathrm{W} 1$ rats.

rapidly on transfer to the warm chamber. All six bones measured in both A and B rats reached the same length as those of the W2 rats at different times; nevertheless, the most distally placed $\mathrm{Cd} 23$ of tail and the mid-phalanx 3 of hind limb were always the first or among the earliest bones to catch up with the controls.

From the radiographs the epiphyses of all the bones measured, except $\mathrm{Cd} 23$, were already present at the beginning of the experiment. In the control rats both the upper and lower epiphyses of $\mathrm{Cd} 23$ appeared by the end of the second experimental week. Cold exposure seemed to have a particularly adverse effect on epiphyseal development, for the epiphyses of $\mathrm{Cd} 23$ were not found in every AT rat until the 4th experimental week; and they did not appear in all the $\mathrm{C}$ rats 
until the 14th week. The epiphyses of $\mathrm{Cd} 23$ were developed in all A rats 2 weeks after removal from the cold room.

Transverse lines of arrested growth were present in the radiographs of the bodies of the caudal vertebrae in the rats exposed to cold (Fig. 6). In the $\mathrm{C}$ rats,

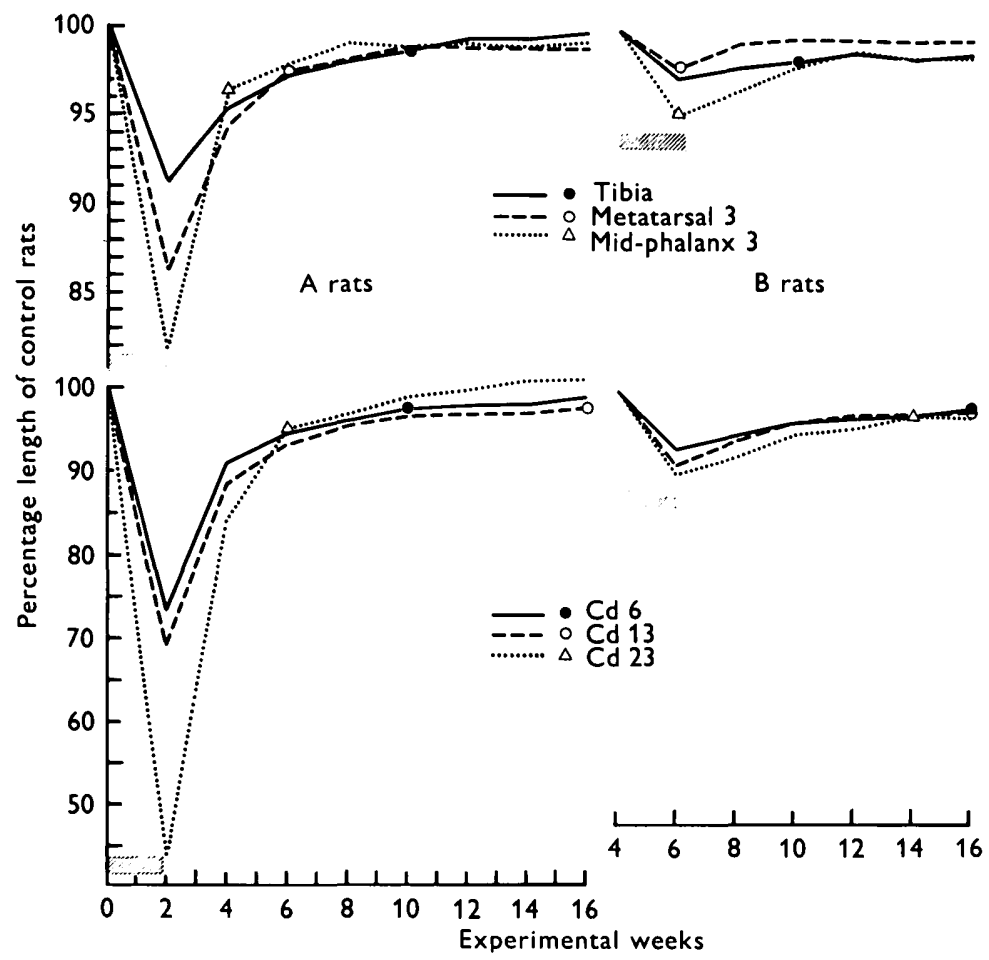

Fig. 5. Bone lengths of $A$ and $B$ rats shown as percentages of $\mathrm{W} 2$ rats. Marks on curves indicate time when bone lengths of A or B rats became insignificantly shorter than those of W2. Shaded areas show periods of cold exposure.
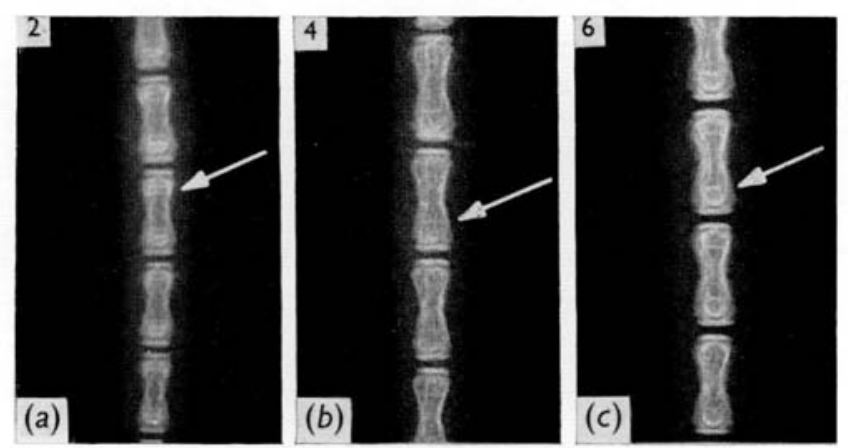

Fig. 6. Transverse lines of arrested growth in the metaphyses of caudal vertebrae after cold exposure. (a) Two lines in AT rats, $(b)$ one thin line in A rats, $(c)$ one thick line in $\mathrm{C}$ rats. Numbers indicate the experimental week. 
one clear line was found in the metaphysis; and this line, beginning to appear in the 4th experimental week, persisted to the end. In the AT rats, two lines in the metaphysis were observed after the first cold-warm cycle; further cold exposures did not produce any more clear lines. In the A rats, one thin line was seen 2 weeks after being taken out of the cold room. In the B rats, on the other hand, cold exposure at an older age did not produce any observable transverse line.

\section{DISCUSSION}

Reduced growth rate in a cold environment has been attributed to local vascular phenomena. Cold exposure causes vasoconstriction, which results in vascular insufficiency to the tissues concerned (Chevillard et al. 1963), and a consequent growth retardation. Similarly, the distal segments of the appendicular bones are affected to a greater degree than the proximal segments, since the attenuating vessels in the distal ends of the appendages are more vulnerable to cold (Lee, Chu \& Chan, 1969). During the recovery period the substantial increase in growth rate occurs only after relief of this vascular impediment.

Previous authors have shown clear evidence of the increase of thyroid activity in rats after exposure to low environmental temperature, as manifested by the increase in weight, in vascularity, in follicular epithelial height, and in hormone secretion of the thyroid gland (Sellers \& You, 1950; Rand, Riggs \& Talbot, 1952; Cottle \& Carlson, 1956; Woods \& Carlson, 1956; Weiss, 1957; Johnson, Kibler \& Silsby, 1964). When exogenous thyroxine was given to rats which had received 3-week propylthiouracil administration, Hsieh (1962) found that those rats required a 16 -fold increase of thyroid hormone for optimum growth in $5{ }^{\circ} \mathrm{C}$. In our Exp. I the $\mathrm{C}$ rats showed marked decrease in growth rate during the first 2-4 weeks in the cold, after which the growth rate became similar to that of the W1 controls. The 2-4 weeks' period for establishing cold adaptation most likely represents the time required for the development of adequate thyroid hyperplasia to meet the rats' increased need. In our Exp. II the A and B rats should have developed some degree of thyroid hyperplasia during the fortnight's cold exposure. After returning to a warm environment, and before the completion of thyroid involution, the superfluous thyroid hormone secreted may play an important role in the transient rapid compensatory growth, analogous to the transient effect of this hormone on human growth described by Tanner $(1963 b)$. The validity of this postulate may be tested by performing surgical thyroidectomies on rats after a period of cold exposure and then determining the amount of exogenous thyroxine required to maintain adequate compensatory growth. This should competently reflect the role of thyroid activity in compensatory growth after cold stunting.

Under the conditions of the present experiments, a true linear relationship was demonstrated between the amount of stunting and the magnitude of compensatory growth. Deflexion from straight line would be expected should 
the experimental conditions vary, e.g. cold exposure being more intense or prolonged, or occurring at a much younger age.

Transverse lines of arrested growth were clearly seen only in the metaphyses of caudal vertebrae and not in the other bones because the tail is most severely affected by cold. Again, the lines were produced only in rats exposed to cold at a very young age when the growth vigor is great, and the effect of stunting more serious. According to our daily tail-length measurement of the AT rats during the early part of the experimental period, the tail in fact never stopped growing, even on the first day of exposure to $5{ }^{\circ} \mathrm{C}$. The transverse lines are therefore not necessarily caused by actual cessation of growth, but may be produced by marked retardation.

\section{SUMMARY}

Male albino rats were kept in rooms at $28^{\circ} \mathrm{C}$ or $5{ }^{\circ} \mathrm{C}$ for 16 weeks. Experiment I began with 26-day-old rats: $\mathrm{W} 1$ rats at $28^{\circ} \mathrm{C}, \mathrm{C}$ rats at $5^{\circ} \mathrm{C}$, and AT rats at $5{ }^{\circ} \mathrm{C}$ and $28^{\circ} \mathrm{C}$ in alternating weeks. Experiment II began with 23-day-old rats: W 2 rats at $28^{\circ} \mathrm{C}$; A and $\mathrm{B}$ rats exposed to $5{ }^{\circ} \mathrm{C}$ for 2 weeks (A rats during first 2 weeks, B rats during 5th and 6th weeks), and then transferred back to $28^{\circ} \mathrm{C}$.

$\mathrm{C}$ rats showed marked cold stunting of tail- and body-length measurements. AT rats showed fluctuating growth rates after the temperature changes; their final tail length, but not body length, was less than that of $\mathrm{W} 1$ rats. After 2 weeks of cold exposure the younger A rats were more severely stunted than the older $\mathrm{B}$ rats, but their compensatory growth was greater and lasted longer. A and B rats reached similar lengths as W 2 rats around the 7 th and 10th weeks. A positive linear relationship between amount of stunting and increased growth rate during the compensatory period was demonstrated for both tail and body lengths.

Radiographic measurements of the lengths of three caudal vertebrae and three hind-limb bones showed a disto-proximal stunting gradient in C and AT rats. In $\mathrm{A}$ and $\mathrm{B}$ rats, the stunting gradient disappeared soon after returning to $28{ }^{\circ} \mathrm{C}$; the six bones caught up with the controls at different times.

\section{RÉSUMÉ}

Degré et allure de la croissance compensatrice ou de rattrapage chez des rats après traitement au froid

Des rats albinos mâles ont été maintenus dans des chambres à $28^{\circ} \mathrm{C}$ ou $5^{\circ} \mathrm{C}$ pendant 16 semaines. L'expérience $\mathrm{I}$ a débuté avec des rats âgés de 26 jours: des rats $\mathrm{W} 1$ à $28^{\circ} \mathrm{C}$, des rats $\mathrm{C}$ à $5{ }^{\circ} \mathrm{C}$ et des rats AT alternativement, de semaine en semaine, à $5{ }^{\circ} \mathrm{C}$ et à $28^{\circ} \mathrm{C}$. L'expérience II a débuté avec des rats de 23 jours: des rats $\mathrm{W} 2$ à $28^{\circ} \mathrm{C}$, des rats $\mathrm{A}$ et $\mathrm{B}$ ont été exposés à $5{ }^{\circ} \mathrm{C}$ pendant 2 semaines (les rats $\mathrm{A}$ pendant les deux premières semaines, les rats $\mathrm{B}$ pendant les $5 \mathrm{e}$ et $6 \mathrm{e}$ semaines), ensuite remis à $28^{\circ} \mathrm{C}$.

Les rats $\mathrm{C}$ ont montré une inhibition marquée de la croissance de la queue et 
de la longueur du corps. Les rats AT ont montré des vitesses de croissances fluctuantes d'après les changements de température; leur longueur de queue finale, mais non celle du corps, était inférieure à celle des rats W 1 . Après 2 semaines d'exposition au froid, l'inhibition de croissance des jeunes rats $\mathrm{A}$ était plus forte que celle des rats $B$ plus âgés, mais leur croissance de rattrapage était plus forte et de plus longue durée. Les rats $\mathrm{A}$ et $\mathrm{B}$ ont atteint une longueur égale à celle des rats $\mathrm{W} 2$ aux environs des $7 \mathrm{e}$ et $10 \mathrm{e}$ semaines. Une relation linéaire positive entre le degré d'inhibition et l'augmentation de croissance au moment du rattrapage a pu être démontrée.

Des mesures radiographiques de la longueur des trois dernières vertèbres caudales et des trois os du membre postérieur ont montré un gradient distoproximal d'inhibition de croissance chez les rats $\mathrm{C}$ et $\mathrm{AT}$. Chez les rats $\mathrm{A}$ et $\mathrm{B}$, le gradient d'inhibition a bientôt disparu après le retour à $28^{\circ} \mathrm{C}$; les os ont rattrapé leurs témoins à des temps différents.

We are most grateful to Professor K. S. F. Chang for valuable suggestions.

\section{REFERENCES}

Chevillard, L., Portet, R. \& Càdot, M. (1963). Growth rate of rats born and reared at $5^{\circ} \mathrm{C}$ and $30^{\circ} \mathrm{C}$. Fedn. Proc. Fedn Am. Socs exp. Biol. 22, 699-703.

Cottle, M. \& CARLson, L. D. (1956). Turnover of thyroid hormone in cold exposed rats determined by radioactive iodine studies. Endocrinology 59, 1-11.

Heroux, O. \& Gridgeman, N. T. (1958). The effect of cold acclimation on the size of organs and tissues of the rat, with special reference to modes of expression of results. Can. J. Biochem. Physiol. 36, 209-16.

Hsien, A. C. L. (1962). The role of the thyroid in rats exposed to cold. J. Physiol., Lond. 161, $175-88$.

Johnson, H. D., KibleR, H. H. \& Silsby, H. (1964). The influence of ambient temperatures of $9{ }^{\circ} \mathrm{C}$ and $28{ }^{\circ} \mathrm{C}$ on thyroid function of rats during growth and aging. Gerontologia 9 , $18-27$.

Lee, M. M. C., Chu, P. C. \& Chan, H. C. (1969). Effect of cold on the skeletal growth of albino rats. Am. J. Anat. (In the Press.)

Rand, C. G., Riggs, D. S. \& TAlBot, N. B. (1952). The influence of environmental temperature on the metabolism of the thyroid in the rat. Endocrinology 51, 562-9.

Sellers, E. A. \& You, S. S. (1950). Role of thyroid in metabolic responses to a cold environment. Am. J. Physiol. 163, 91.

Snedecor, G. W. (1956). Statistical methods, 5th ed. Ames, Iowa: Iowa State College Press.

TANNER, J. M. (1963a). Regulation of growth in size in mammals. Nature, Lond. 199, 845-50.

TANner, J. M. (1963b). The regulation of human growth. Child Dev. 34, 817-48.

Weiss, A. K. (1957). Tissue responses in the cold-exposed rat. Am. J. Physiol. 188, 430-4.

Woods, R. \& Carlson, L. D. (1956). Thyroxine secretion in rats exposed to cold. Endocrinology 59, 323-30.

(Manuscript received 16 August 1968, revised 13 January 1969) 